\title{
Yield survey and nutritional evaluation of garlic stalk for ruminant feed
}

\author{
Y. H. Lee ${ }^{1}$, Y. I. Kim', Y. K. Oh², F. Ahmadi ${ }^{1}$ and W. S. Kwak ${ }^{1 *}$
}

\begin{abstract}
Background: Very limited information exists on the ruminal degradation kinetics of nutrients in garlic stalk. The present study aimed to survey the annual yield of garlic stalk in Korea and determine its feed-nutritive value for ruminants.

Methods: In Experiment 1, garlic stalk was incubated in situ in the rumen of two Hanwoo steers (360 $\pm 15 \mathrm{~kg}$ body weight) and removed after 12, 24, or $48 \mathrm{~h}$ to determine the ruminal degradation kinetics of DM and NDF. Rice straw was also included for comparison. In Experiment 2, In Experiment 2, six male Corriedale sheep were randomized to two dietary treatments to determine the apparent digestibility of nutrients in garlic stalk. Diets included a control ration without garlic stalk ( $60 \%$ concentrate mix $+40 \%$ ryegrass) or a treatment ration ( $70 \%$ control diet $+30 \%$ garlic stalk).

Results: The Korean national yield of garlic stalk (sun-dried basis) in 2016 was estimated to be 31,910 tons, with the southern coastal regions producing the highest quantity. Compared with rice straw, garlic stalk had lower NDF, higher $A D F$, and greater effective degradabilities of DM and NDF, resulting in a greater TDN value (56.3\%), which was higher than that obtained for rice straw (43.7\%).

Conclusion: These results provide basic information on the ruminal DM and NDF degradation kinetics of garlic stalk, which would be helpful for the efficient utilization of this by-product in ruminant diets.
\end{abstract}

Keywords: Garlic stalk, Nutritional value, Rice straw, Ruminal degradation, Yield

\section{Background}

Garlic (Allium sativum L.) is a flavoring spice with an annual production of approximately 20 million tons in the world, with China, India, and Korea being the main producers [1]. A recent review [2] on garlic processing waste reported the increasing trend in global demand for garlic consumption, leading to the substantial waste production $[25-30 \%$ solid waste], where husk and straw (collectively known as garlic stalk) constitute the major waste by-product. However, garlic stalk, generated abundantly during the harvesting period, is usually made into compost or incinerated $[3,4]$. Therefore, problems associated with disposal costs and environmental pollution are emerging, and solutions are needed [5].

To efficiently utilize garlic processing by-product and mitigate the environmental concerns associated with its accumulation in landfills, garlic by-products have been evaluated as a biomass for bioenergy production [6], soil

\footnotetext{
* Correspondence: wsk@kku.ac.kr

${ }^{1}$ Division of Food Bio-science, College of Medical Life Sciences, Konkuk

University, ChungjuChung-BukRepublic of Korea

Full list of author information is available at the end of the article
}

amendment [7] or bio-adsorbent [8]. However, the use of garlic by-products as a source of animal feed is still the most promising and viable route for efficient utilization of this waste resource [2]. Previous studies on garlic stalk silage have indicated that it contains a moderate amount of protein (9.3-13.0\%) and a high concentration of NDF (48$59 \%)[4,9,10]$, which may be a potential source of roughage for ruminant animals. In general, the use of human-inedible resources, such as garlic stalk, as a source of animal feed would help to minimize the problem of feed inadequacy, potentially reducing feed costs, which constitute the majority of production costs, and reducing the problems associated with the disposal of this waste resource. However, to efficiently utilize garlic stalk in ruminant diets, accurate information on the ruminal degradation kinetics of its nutrients is required. Recently, Kamruzzaman et al. [10] reported that replacing $10 \%$ of hay (orchardgrass and reed canarygrass) with garlic stem and leaf silage in sheep diet resulted in greater $\mathrm{N}$ and energy utilization without detrimental effects on ruminal fermentation. Chu et al. [9] reported an improvement in meat quality and economic 
income when garlic stalk silage was fed to steers during the fattening period. More recently, Panthee et al. [11] reported that inclusion of garlic leaves at $2.5 \mathrm{~g} /\left(\mathrm{kg} \mathrm{BW}^{0.75} \cdot \mathrm{d}\right)$ had no negative effects on ruminal fermentation characteristics and had positive $\mathrm{N}$ utilization in sheep. These studies investigated the feed value of garlic stalk silage for beef cattle, or the bioactive components in garlic stem and leaf silage for sheep. However, to our knowledge, no information exists on the ruminal degradation kinetics of nutrients in garlic stalk. Therefore, the current study was undertaken to estimate the yield of garlic stalk in Korea, and to evaluate ruminal degradation kinetics and the feeding value of garlic stalk for sheep.

\section{Methods}

\section{Annual yield estimation}

The annual garlic yield in the major garlic-cultivating provinces in Korea was surveyed in four consecutive years (2013-2016) to estimate the quantity of garlic stalk production. Survey data were obtained from the National Statistics Office [12]. The yield of garlic stalk (wet basis) was estimated as a proportion of total garlic production [total garlic production $\times 73.6 \%$ ]. The annual yield of garlic stalk (sun-dried basis) was calculated according to the following equation:

Yield of sun-dried garlic stalk

$$
=\frac{\text { Yield of wet garlic stalk } \times \text { DM content }(\%) \text { of wet garlic stalk }}{\text { DM content }(\%) \text { of garlic stalk (sun-dried basis) }}
$$

The DM content of wet and sun-dried garlic stalk was 13.6 and $86.4 \%$, respectively.

\section{Sample collection and chemical analyses}

Garlic stalk (sun-dried) was obtained from a garlic processing plant located in Uysung County, Kyungbuk Province, and an agricultural fishery marketing center located in Chungju city (Chungbuk Province, Korea). To ensure representative sampling, the samples were collected eight times between July 2015 and February 2016. Prior to chemical analysis, samples were dried and then ground to pass through a 1-mm screen (Cemotec, Tecator, Skanor, Sweden). The DM, CP, ether extract (EE), crude fiber (CF), ash, NDF (with $\alpha$-amylase and sodium sulfite), and ADF contents were determined according to the standard methods of the Association of Official Analytical Chemists [13]. Lignin was measured after $72 \%(w /$ w) sulfuric acid solubilization of cellulose. Nitrogen associated with ADF (acid detergent insoluble CP; ADICP) was measured according to the methods described by Licitra et al. [14]. True protein was measured following the precipitation of $\mathrm{N}$ fractions in trichloroacetic acid solution (5\%).

\section{Experiment 1: In situ study}

All animal care protocols were approved by the Konkuk University Institutional Animal Care and Use Committee. Two cannulated Hanwoo steers (body weight $=360 \pm 15 \mathrm{~kg}$; mean \pm standard deviation) were used for the in situ experiment, which was conducted in three separate runs on different days. The animals were fed $5 \mathrm{~kg}$ of a corn-based concentrate mix (DM 89.8\%, CP 14.3\%, EE 3.0\%, crude ash 7.5\%, CF 6.26\%, NDF 29.6\%, and ADF 17.2\%) and $2 \mathrm{~kg}$ of rice straw daily to meet the nutrient requirements for early fattening steers [15]. The in situ trial was performed according to the method of Ørskov et al. [16] as previously described in detail [17]. In brief, the experimental samples were milled to pass through a $2-\mathrm{mm}$ sieve (Cemotec, Tecator, Skanor, Sweden), and then a 5-g sample (DM basis) was placed into a Dacron bag $(10 \times 20 \mathrm{~cm}$, $53 \pm 10-\mu \mathrm{m}$ pore size; R1020, Ankom Technology, Macedon, NY, USA). Two-hours after the morning feeding, the bags were incubated in triplicate, in the ventral ruminal sac for 12, 24, or $48 \mathrm{~h}$. At the end of the incubation, bags were retrieved, washed under running cold water until the water leaving the bag was clear, and then dried in an oven at $55{ }^{\circ} \mathrm{C}$ for $48 \mathrm{~h}$ until analysis. The soluble A fraction (washout fraction) was determined after the 0 -h bags were washed in a washing machine $\left(25^{\circ} \mathrm{C}\right.$ for $\left.40 \mathrm{~min}\right)$. The in situ DM and NDF data were fitted to the following firstorder kinetic model [16]:

$$
\mathrm{Y}=\mathrm{A}+\mathrm{B}\left[1-\mathrm{e}^{-K \mathrm{~d}(t)}\right],
$$

where, $\mathrm{Y}=$ ruminal disappearance rate at time $t ; \mathrm{A}=\mathrm{im}$ mediately soluble fraction; $\mathrm{B}=$ potentially degradable fraction; $K_{\mathrm{d}}=$ degradation rate of the degradable $\mathrm{B}$ fraction; and $t=$ incubation time.

\section{Experiment 2: In vivo study}

Six Corriedale rams (body weight $=51.0 \pm 2.0 \mathrm{~kg}$; mean \pm standard deviation) were distributed randomly to receive one of two diets (14-day adaptation period and 7day collection period). Dietary treatments included a control diet $(60 \%$ concentrate mix $+40 \%$ ryegrass; $11.2 \% \mathrm{CP}$, 1.9\% EE, 22.8\% CF, 55.6\% NDF, 35.7\% ADF, 7.6\% crude ash, and $56.5 \%$ NFE) and a treatment diet, where $30 \%$ of the control diet was replaced with garlic stalk ( $70 \%$ control diet $+30 \%$ garlic stalk; 9.7\% CP, 1.8\% EE, $26.7 \%$ CF, $54.0 \%$ NDF, 39.9\% ADF, $10.1 \%$ crude ash, and 51.8\% NFE). The chemical compositions of the concentrate mix, ryegrass, and garlic stalk, used in the formulation of experimental diets, are listed in Table 1. Diets were mixed daily and offered (1.7\% of body weight; $850 \mathrm{~g}$ DM basis) twice daily in equal portions at 07:00 and 18:00 h. Diets were formulated to meet the nutrient requirement of sheep [18]. Animals always had free access to fresh water. During the experiment, the animals were kept in individual metabolism 
Table 1 Chemical composition of ingredients fed to sheep

\begin{tabular}{|c|c|c|c|}
\hline Item, \% of DM & Concentrate mix & Ryegrass straw & Garlic stalk \\
\hline Dry matter, \% & 87.5 & 91.4 & 88.8 \\
\hline Organic matter & 90.6 & 95.0 & 84.0 \\
\hline Ether extract & 2.91 & 0.53 & 1.40 \\
\hline Crude protein (CP) & 15.6 & 4.52 & 6.21 \\
\hline True protein, $\%$ of CP & 87.4 & 87.2 & 79.8 \\
\hline $\mathrm{NPN}^{\mathrm{a}}, \%$ of $\mathrm{CP}$ & 12.6 & 12.8 & 20.2 \\
\hline$A D I C P^{b}, \%$ of $C P$ & 24.7 & 43.4 & 37.3 \\
\hline Neutral detergent fiber & 39.1 & 80.4 & 50.2 \\
\hline Acid detergent fiber & 23.4 & 54.3 & 49.6 \\
\hline Hemicellulose & 15.7 & 26.0 & 0.63 \\
\hline Crude fiber & 10.4 & 41.3 & 35.7 \\
\hline Ash & 9.40 & 5.02 & 16.0 \\
\hline Nitrogen-free extract & 61.7 & 48.7 & 40.7 \\
\hline
\end{tabular}

${ }^{\mathrm{a} N P N}$ Non-protein nitrogen

${ }^{\mathrm{b}} \mathrm{ADICP}$ Acid detergent insoluble CP

crates $(1.6 \times 0.5 \mathrm{~m})$, which permitted the collection of feces. Daily fecal output during the collection period was dried at $65{ }^{\circ} \mathrm{C}$ for $48 \mathrm{~h}$. Feces were thoroughly mixed at the end of the collection period to obtain a composite sample. The TDN value in garlic stalk was estimated using the values of digestible CP, EE, CF, and NFE [19].

\section{Statistical analysis}

Experimental feeds were sampled eight times during 20152016, with the following resultant experimental design: two feeds (garlic stalk and rice straw) $\times$ eight batches $\times$ three analytical replicates (per feed per batch), giving a total of 48 observations. The data were analyzed according to the following model: $Y_{i j}=\mu+F_{i}+R_{j}+e_{i j}$, where, $Y_{i j}=$ response variable; $\mu=$ mean; $F_{i}=$ fixed effect of feeds $(i=2) ; R_{j}=$ random effect of batch $(j=8)$; and $\mathrm{e}_{\mathrm{ij}}=$ error term.

In situ data were obtained over the course of three runs in different days, resulting in the following experimental design: three incubation runs $\times$ two feeds (garlic stalk and rice straw) $\times$ two animal replicates $\times$ three sample replicates, giving a total of 36 observations. The data were analyzed according to the following model: $Y_{i j}=\mu+F_{i}+R_{j}+e_{i j}$, where, $Y_{i j}=$ response variable; $\mu=$ mean; $F_{i}=$ fixed effect of feeds $(i=2) ; R_{j}=$ random effect of incubation run $(j=3)$; and $\mathrm{e}_{\mathrm{ij}}=$ error term. When a significant difference was found, least-squares means were separated using Student's $t$-test [20]. A P-value less than 0.05 was considered significant.

\section{Results}

Annual yield of sun-dried garlic stalk

The annual yield of garlic stalk production (from 2013 to 2016) in major provinces in Korea is shown in Table 2. An approximate quantity of 303,297 tons of garlic stalk (wet basis) was produced in 2013, which then followed a decreasing trend until 2015. An estimated quantity of 31,910 tons of garlic stalk (sun-dried) was generated in 2016, when the highest amount was produced in Gyeongnam, accounting for $25.4 \%$ of the total production quantity, followed by Jeonnam, Gyeongbuk, Chungnam, and Jeju.

\section{Chemical composition}

The chemical compositions of garlic stalk and rice straw are shown in Table 3. Garlic stalk had a higher $(P<0.05)$ content of DM, CP, ADF, ash, and NFC, and lower NDF and lignin contents than rice straw. The ADICP concentration did not differ between garlic stalk and rice straw.

\section{Ruminal degradation kinetics of DM and NDF}

The in situ DM and NDF fractions of garlic stalk are shown in Table 4. The mean soluble A fraction of DM tended to be slightly greater $(P=0.06)$ in garlic stalk than in rice straw. The degradable B fraction of DM was 2.7times greater in garlic stalk than in rice straw, resulting in a lower $(2.55$-fold decrease; $P<0.001)$ percentage of ruminally undegradable DM in garlic stalk than in rice straw. The degradation rate of the degradable B fraction for DM, within $48 \mathrm{~h}$ of rumen incubation, tended to be greater $(P=0.07)$ in garlic stalk than in rice straw. The mean soluble A fraction of NDF did not differ between garlic stalk and rice straw. The degradable $\mathrm{B}$ and undegradable $\mathrm{C}$ fractions were 2.03-times higher and 2.18-times lower in garlic stalk than in rice straw, respectively. Garlic stalk exhibited a higher fractional rate of NDF degradation than rice straw. Based on this rate, the time required for half the $B$ fraction of NDF to be degraded in the rumen was estimated to be $12 \mathrm{~h}$ for garlic stalk.

The effective DM and NDF degradability of garlic stalk and rice straw are shown in Table 5. Effective degradability of DM, assuming a passage rate of $0.05 \mathrm{~h}^{-1}$, was found to be 2.3 -fold greater in garlic stalk than in rice straw. Similarly, effective degradability of NDF, assuming a passage rate of $0.05 \mathrm{~h}^{-1}$, was 2.97 -times greater in garlic stalk than in rice straw.

The rates of in situ DM and NDF disappearance from rice straw and garlic stalk, as a function of residence time $(48 \mathrm{~h})$ in the rumen, are illustrated in Fig. 1. The extent of DM and NDF disappearance from garlic stalk was considerably greater than that from rice straw; approximately 53.1 and $43.4 \%$ of DM and NDF in garlic stalk were disappeared during the first $12 \mathrm{~h}$ of incubation, compared to only 10.4 and $3.3 \%$ in rice straw, respectively.

\section{Total digestible nutrients of garlic stalk}

The apparent digestibility coefficients of DM, EE, CP, $\mathrm{CF}$, and NFE in the control diet $(60 \%$ concentrate mix $+40 \%$ ryegrass) were $63.6,84.7,62.0$, and $72.6 \%$, respectively, resulting in a TDN value of $63.8 \%$ (Table not 
Table 2 Production quantity of garlic stalk in Korean provinces: 2013-2016

\begin{tabular}{|c|c|c|c|c|}
\hline \multirow[t]{2}{*}{ Item, tons } & \multicolumn{4}{|l|}{ Year } \\
\hline & 2013 & 2014 & 2015 & 2016 \\
\hline \multicolumn{5}{|l|}{ Production of garlic stalk (wet basis) } \\
\hline Metropolis $^{a}$ & 4352 & 3957 & 2983 & 6484 \\
\hline Gyeonggi & 5448 & 4657 & 4454 & 4536 \\
\hline Gangwon & 2604 & 1877 & 1755 & 1068 \\
\hline Chungbuk & 4150 & 3200 & 3149 & 3596 \\
\hline Chungnam & 29,671 & 25,729 & 20,190 & 23,065 \\
\hline Jeonbuk & 5285 & 6357 & 5046 & 7688 \\
\hline Jeonnam & 80,386 & 70,925 & 48,600 & 43,621 \\
\hline Gyeongbuk & 50,208 & 43,997 & 33,843 & 40,354 \\
\hline Gyeongnam & 80,259 & 66,401 & 52,979 & 51,407 \\
\hline Jeju & 40,934 & 33,167 & 22,902 & 20,904 \\
\hline Total production of garlic stalk ${ }^{\mathrm{b}}$ (wet basis) & 303,297 & 260,267 & 195,900 & 202,723 \\
\hline Total production of garlic stalk (sun-dried basis) & 47,741 & 40,968 & 30,836 & 31,910 \\
\hline
\end{tabular}

${ }^{a}$ Seoul, Busan, Daegu, Incheon, Gwangju, Daejeon, Ulsan, and Sejong metropolises

${ }^{\mathrm{b}}$ Calculated as the total production of garlic $\times 73.6 \%$

${ }^{c}$ Calculated as the total production of wet garlic stalk $\times 13.6 \% / 86.4 \%$

presented). Likewise, total-tract digested DM, EE, CP, $\mathrm{CF}$, and NEF in the treatment diet $(70 \%$ control diet and $30 \%$ sun-dried garlic stalk) were $62.6,68.6,54.9$, and $71.6 \%$, respectively. The digestibility coefficients of DM, $\mathrm{EE}, \mathrm{CP}, \mathrm{CF}$, and NFE in garlic stalk, calculated as the difference between the digestibility coefficients of control and treatment diets, were estimated to be $60.2,20.4$, $26.7,72.6$, and $68.0 \%$, respectively, resulting in a TDN value of $56.3 \%$.

\section{Discussion}

The quantity of garlic stalk produced in 2013 was the highest of all the years included in this study, in the order of Jeonnam > Gyeongnam > Gyeongbuk > Jeju > Chungnam provinces, indicating that the highest quantities were produced in the southern regions. Garlic is the major overwintering crop widely cultivated in the southern and central regions of Korea, and is largely divided into tropical and temperate garlic [21]. Tropical garlic contributes to $77 \%$ of garlic production in Korea and its major production areas are high-temperature regions such as the southern coast, Jeju island, Shinhan, Muahn, Haenam, Goheung, and Namhae counties [22].

\section{Chemical composition}

Although the mean values for $\mathrm{CP}$ and $\mathrm{EE}$ observed in the present investigation were lower than those reported by Chu et al. [9] for garlic stalk silage, comparable values were found for CF, ash, and NFE contents. Contents of $\mathrm{CP}$ and NDF, as reported by Kamruzzaman et al. [10] for garlic stem and leaf silage, were higher and lower than those obtained in our study, respectively. The

Table 3 Chemical composition of garlic stalk and rice straw

\begin{tabular}{|c|c|c|c|c|}
\hline Item, \% of DM & Garlic stalk & Rice straw & SE & $P$-value \\
\hline Dry matter, \% & 84.6 & 70.0 & 2.71 & $<0.001$ \\
\hline Crude protein (CP) & 5.5 & 4.0 & 0.53 & 0.018 \\
\hline Acid detergent insoluble $\mathrm{CP}, \%$ of $\mathrm{CP}$ & 35.3 & 29.6 & 4.52 & 0.385 \\
\hline Ether extract & 1.5 & 0.9 & 0.15 & 0.006 \\
\hline Neutral detergent fiber (NDF) & 54.9 & 70.6 & 1.48 & $<0.001$ \\
\hline Acid detergent fiber & 54.6 & 44.3 & 1.38 & $<0.001$ \\
\hline Hemicellulose & 0.3 & 26.3 & 2.40 & $<0.001$ \\
\hline Ash & 13.8 & 11.9 & 2.01 & $<0.001$ \\
\hline Lignin & 3.8 & 5.1 & 0.12 & $<0.001$ \\
\hline Non-fiber carbohydrates ${ }^{a}$ & 24.3 & 12.7 & 2.09 & $<0.001$ \\
\hline
\end{tabular}

${ }^{a}$ Calculated as $100-[C P+N D F+$ ether extract + ash $]$ 
Table 4 In situ fractionation of dry matter and neutral detergent fiber in garlic stalk and rice straw

\begin{tabular}{|c|c|c|c|c|}
\hline Item & Garlic stalk & Rice straw & SE & $P$-value \\
\hline \multicolumn{5}{|l|}{ Dry matter fractions (\%) } \\
\hline $53-\mu \mathrm{m}$ filterable and soluble A fraction & 13.6 & 11.6 & 0.8 & 0.059 \\
\hline Degradable B fraction & 60.5 & 22.4 & 3.0 & $<0.001$ \\
\hline Undegradable C fraction ${ }^{\mathrm{a}}$ & 25.9 & 66.0 & 2.8 & $<0.001$ \\
\hline$K_{d} B^{b}\left(\% h^{-1}\right)$ & 8.2 & 5.0 & 1.5 & 0.072 \\
\hline \multicolumn{5}{|l|}{ Neutral detergent fiber fractions (\%) } \\
\hline 53- $\mu \mathrm{m}$ filterable and soluble A fraction & 2.0 & 1.4 & 1.0 & 0.631 \\
\hline Degradable B fraction & 68.0 & 33.5 & 4.2 & $<0.001$ \\
\hline Undegradable C fraction & 30.0 & 65.1 & 4.1 & $<0.001$ \\
\hline$K_{\mathrm{d}} \mathrm{B}\left(\% \mathrm{~h}^{-1}\right)$ & 7.8 & 3.3 & 0.9 & 0.001 \\
\hline
\end{tabular}

a Calculated as $100-(A+B)$

${ }^{\mathrm{b}} K_{\mathrm{d}} \mathrm{B}=$ degradation rate of the degradable $\mathrm{B}$ fraction

chemical composition of garlic stalk showed that the NDF content was comparable to that of alfalfa [23]; however, the NDF content was lower than that found for timothy (83.4\%) and ryegrass (78.9\%) [24], which are imported in large amounts to Korea [25].

\section{In situ degradation kinetics}

To our knowledge, no previous study has investigated the in situ DM and NDF degradation kinetics of garlic stalk; therefore, it was not possible to compare these values with those reported previously. Comparison of the in situ DM fractionations of garlic stalk in the present investigation with those reported for alfalfa hay by our research team [24] showed that garlic stalk exhibited a much lesser soluble A faction and greater degradable B fraction (60.5 vs. $21.8 \%$ ) than alfalfa hay. The undegradable $C$ fraction was also found to differ largely between the two feeds ( 25.9 vs. $46.3 \%$ for garlic stalk and alfalfa hay, respectively). A positive correlation exists between the soluble A fraction and the NFC content of feeds [26], which may help to explain the greater soluble A fraction of DM in garlic stalk compared with rice straw, as the difference in NFC content among the two feeds was large ( 24.3 vs. $12.7 \%$ for garlic stalk and rice straw, respectively).

Table 5 In situ effective degradability of dry matter and neutral detergent fiber at two rates of rumen passage ${ }^{a}$

\begin{tabular}{lllll}
\hline Item, \% & Garlic stalk & Rice straw & SE & $P$-value \\
\hline Effective degradability of DM & & & & \\
$K_{\mathrm{p}} \mathrm{B}=0.025, \mathrm{~h}^{-1}$ & 59.6 & 25.8 & 3.2 & $<0.001$ \\
$K_{\mathrm{p}} \mathrm{B}=0.050, \mathrm{~h}^{-1}$ & 50.9 & 22.2 & 3.1 & $<0.001$ \\
Effective degradability of NDF & & & & \\
$K_{\mathrm{p}} \mathrm{B}=0.025, \mathrm{~h}^{-1}$ & 53.1 & 20.1 & $3.5<$ & $<0.001$ \\
$K_{\mathrm{p}} \mathrm{B}=0.050, \mathrm{~h}^{-1}$ & 43.1 & 14.5 & 3.3 & $<0.001$ \\
\hline
\end{tabular}

${ }^{a}$ Effective degradability was calculated as: $\mathrm{A}+\left[\mathrm{B}\left(K_{\mathrm{d}} \mathrm{B} /\left(K_{\mathrm{d}} \mathrm{B}+k \mathrm{k}\right)\right)\right]$, where $\mathrm{A}=$ soluble fraction, $\mathrm{B}=$ degradable fraction, $K_{\mathrm{d}} \mathrm{B}=$ degradation rate of the degradable $\mathrm{B}$ fraction, and $K_{\mathrm{p}}=$ the fractional rate of passage from the rumen
The extent of NDF disappearance for garlic stalk was substantially greater than that for rice straw during a 48-h incubation in the rumen. Hoover [27] studied the factors involved in fiber digestion in the rumen, and found a negative correlation between lignin concentration and fiber digestion. Bruno-Soares et al. [28] also studied the NDF degradation kinetics of several legume straws and found that the concentration and composition of the cell walls (i.e., NDF and lignin) could best explain the variation in the potential degradability of NDF and DM among these straws. For example, these authors reported that the potential degradability of NDF was negatively correlated with NDF $(r=-0.829)$ and lignin $(r=-0.917)$. In the present study, garlic stalk was found to possess a lower concentration of lignin and NDF than rice straw, which may help to explain the difference in the rate of NDF disappearance for garlic stalk and rice straw. However, fiber digestion in the rumen is a very complex process and cannot be explained by the degree of lignification alone. Other factors, including the physical properties of cell walls, such as crystallinity and the degree of polymerization, are involved in the fiber digestion process [29].

The TDN value of garlic stalk (56.3\%) was much higher than that of rice straw (44\%), and comparable with that of medium-quality timothy hay (55.3\%), as reported in the Standard Tables of Feed Composition in Korea [30].

\section{Conclusions}

This study provides basic information on the kinetics of the ruminal DM and NDF degradation of garlic stalk, which are important for its efficient utilization in ruminant diet. The extent and rate of DM and NDF degradation in the rumen and thus TDN content were greater in garlic stalk than in rice straw, 

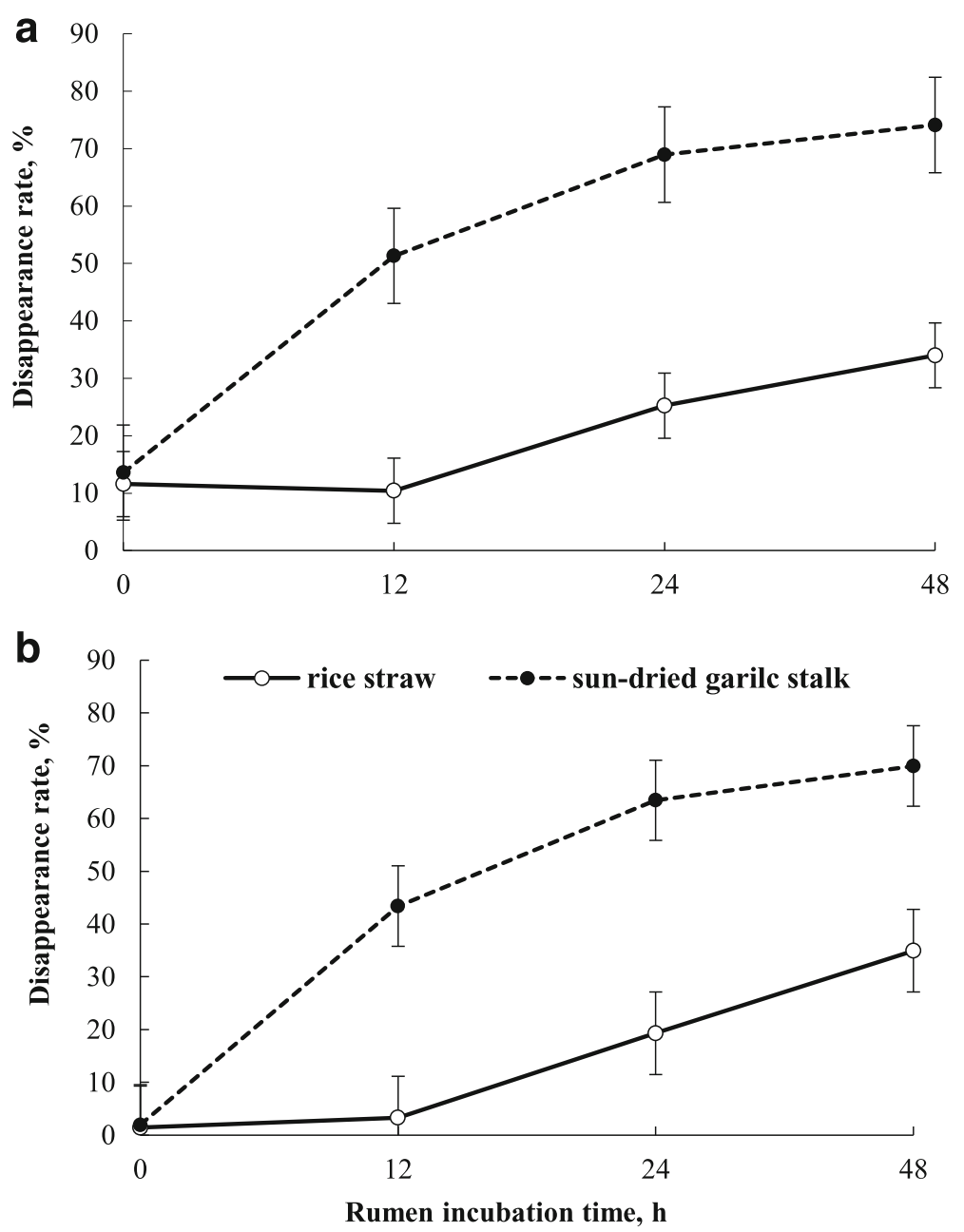

Fig. 1 In situ dry matter (a) and neutral detergent fiber (b) disappearance of sun-dried garlic stalk and rice straw as a function of incubation in the rumen. Error bars indicate standard deviation

which appears to be a good source of roughage for ruminants, especially in places or countries where garlic stalk is abundantly generated. The longerduration in vivo study with the varying inclusion levels of garlic stalk is recommended to evaluate the productive performance responses and determine the proper inclusion level in the diet.

\section{Abbreviations}

ADF: Acid-detergent fiber; ADICP: Acid detergent insoluble CP; CF: Crude fiber; CP: Crude protein; DM: Dry matter; EE: Ether extract; NDF: Neutraldetergent fiber; NFC: Non-fiber carbohydrates; NFE: Nitrogen free extract; NPN: Non-protein nitrogen; TDN: Total digestible nutrients

\section{Acknowledgements}

The authors thank Rural Development Administration (Republic of Korea) for providing the funding source for this study.

\section{Funding}

This study was carried out with the support of the "Cooperative Research program for Agriculture Science and Technology Development (Project No. PJ012507032017)" Rural Development Administration, Republic of Korea.

\section{Availability of data and materials}

Upon request, the corresponding author will provide the data and material supporting the findings of the present study.

\section{Authors' contributions}

YH made chemical and statistical analysis of the study and wrote the manuscript as the first author. $\mathrm{YI}$ and $\mathrm{F}$ assisted the manuscript writing and standard form of the journal, and YK assisted the in situ experiment of the study. WS made substantial contributions to the study conception and design. All authors read and approved the final manuscript.

\section{Ethics approval and consent to participate}

All procedures involving animals were reviewed and approved by the Konkuk University Institutional Animal Care and Use Committee.

\section{Consent for publication}

All the authors have agreed that it should be submitted to Journal of Animal Science and Technology. No part of this work has been published elsewhere or under consideration in another journal. The manuscript has not previously submitted to Journal of Animal Science and Technology.

\section{Competing interests}

We certify that no conflict of interest exists with any financial organization regarding the material discussed in the manuscript. 


\section{Publisher's Note}

Springer Nature remains neutral with regard to jurisdictional claims in published maps and institutional affiliations.

\section{Author details}

'Division of Food Bio-science, College of Medical Life Sciences, Konkuk University, ChungjuChung-BukRepublic of Korea. ${ }^{2}$ Animal Nutrition \& Physiology Team, National Institute of Animal Science, Rural Development Administration, Wanju county 565-851, Jeon-Buk province, Republic of Korea.

Received: 14 June 2017 Accepted: 13 August 2017

Published online: 23 October 2017

\section{References}

1. Faostat - Food and Agriculture Organization of the United Nations, FAO statistical databases, 2014. Available from: http://faostat.fao.org/.

2. Kallel F, Ellouz CS. Perspective of garlic processing wastes as low-cost substrates for production of high-added value products: a review. Environ Prog Sustain Energy. 2017; doi:10.1002/ep.10254.

3. Han X, Cheng Z, Meng H. Soil properties, nutrient dynamics, and soil enzyme activities associated with garlic stalk decomposition under various conditions. PLoS One. 2012;7:e50868.

4. Kamruzzaman M, Liang X, Sekiguchi N, Sano H. Effect of feeding garlic leaf on microbial nitrogen supply, kinetics of plasma phenylalanine, tyrosine and protein synthesis in sheep. Anim Sci J. 2014;85:542-8.

5. Han X, Cheng Z, Meng H, Yang X, Ahmad I. Allelopathic effect of decomposed garlic (Allium sativum L.) stalk on lettuce (L. Sativa Var. Crispa L.). Pak J Bot. 2013:45:225-33.

6. Jian R, Ning P, Li J, Huang X, Qu G. Research of pyrolysis oil and catalysts of garlic stalks. J Agric Sci Technol. 2014;15:1616.

7. Gong B, Bloszies S, Li X, Wei M, Yang F, Shi Q, Wang X. Efficacy of garlic straw application against root-knot nematodes on tomato. Sci Hortic. 2013;161:49-57.

8. Negi R, Satpathy G, Tyagi YK, Gupta RK. Biosorption of heavy metals by utilising onion and garlic wastes. Int J Environ Pollut. 2012;49:179-96.

9. Chu GM, Lee HH, Park JS, Cho HW, Ahn BH. Effect of garlic stalk silage on performance and carcass characteristics of Hanwoo steers. J Anim Sci Technol. 2003:45:1007-18.

10. Kamruzzaman M, Torita A, Sako Y, Al-Mamun M, Sano H. Effects of feeding garlic stem and leaf silage on rates of plasma leucine turnover, whole body protein synthesis and degradation in sheep. Small Rumin Res. 2011;99:37-43.

11. Panthee A, Matsuno A, Al-Mamun M, Sano H. Effect of feeding garlic leaves on rumen fermentation, methane emission, plasma glucose kinetics, and nitrogen utilization in sheep. J Anim Sci Technol. 2017;59:14.

12. National Statistical Office. Agriculture and fisheries statistics division, the Bureau of Social Statistics. Yield of condiment vegetables (Korea statistical information service) 2013.

13. AOAC. Official methods of analysis of AOAC international. 17th ed. Gaithersburg: AOAC; 2000

14. Licitra G, Hernandez T, Van Soest P. Standardization of procedures for nitrogen fractionation of ruminant feeds. Anim Feed Sci Technol. 1996;57: 347-58.

15. National Research Council. Nutrient requirements of beef cattle, Update 2000. Washington, DC: National Academy Press; 2000.

16. Ørskov ER, Hovell FD, Mould F. The use of the nylon bag technique for the evaluation of feedstuffs. Trop Anim Prod. 1980:5:195-213.

17. Lee Y, Ahmadi F, Choi D, Kwak W. In situ ruminal degradation characteristics of dry matter and crude protein from dried corn, high-protein corn, and wheat distillers grains. J Anim Sci Technol. 2016;58:33.

18. National Research Council. Nutrient requirement of small ruminants. Seventh ed. Washington, D.C.: The National Academy Press; 2001.

19. Schneider BH, Flatt WP. The evaluation of feeds through digestibility experiments. Athens: The University of Georgia Press; 1975. p. 151-5.

20. SAS Institute. User's guide: statistics. Cary: SAS Institute Inc.; 2003.

21. Yoon HS, Kang MJ, Hwang CR, Sim HJ, Kim GM. Physicochemical characteristics of garlic (Allium sativum L.) shoots from different areas in Namhae. Kor J Food Preserv. 2014:21:321-7.

22. Jeong $\mathrm{CH}$, Bae $\mathrm{Yl}$, Lee JH, Shim KH, Roh JG, Shin CS, Choi JS. Chemical components and antimicrobial activity of garlics from different cultivated area. J Agric Life Sci. 2009;43:55-9.

23. Lee HS, Lee ID. A comparative study of nutritive value of imported roughages. J Kor Grassl Sci. 2000;20:303-8.
24. Ahmadi F, Lee YH, Ko MJ, Choi DY, Kwak WS. In situ ruminal degradation characteristics of dry matter and crude protein of imported hays marketed to the Korean cattle industry: a field study. J Food Agric Environ. 2017;15:80-5.

25. National Institute of Animal Science. Standard tables of feed composition in Korea. Republic of Korea: Rural Development Administration (RDA); 2007.

26. Kim Y, Cho W, Hong S, Oh Y, Kwak W. Yield, nutrient characteristics, ruminal solubility and degradability of spent mushroom (Agaricus bisporus) substrates for ruminants. Asian-Australas J Anim Sci. 2011;24:1560-8.

27. Hoover W. Chemical factors involved in ruminal fiber digestion. J Dairy Sci. 1986;69:2755-66.

28. Bruno-Soares A, Abreu J, Guedes C, Dias-da-Silva A. Chemical composition, DM and NDF degradation kinetics in rumen of seven legume straws. Anim Feed Sci Technol. 2000;83:75-80.

29. Mertens DR. In: Jung HG, Buxton DR, Hatfield RD, Ralph J, editors. Kinetics of cell wall digestion and passage in ruminants. Madison: Forage Cell Wall Structure and Digestibility; 1993.

30. National Institute of Animal Science. Standard tables of feed composition in Korea, Second revision. Suwon: RDA; 2012.

\section{Submit your next manuscript to BioMed Central and we will help you at every step:}

- We accept pre-submission inquiries

- Our selector tool helps you to find the most relevant journal

- We provide round the clock customer support

- Convenient online submission

- Thorough peer review

- Inclusion in PubMed and all major indexing services

- Maximum visibility for your research

Submit your manuscript at www.biomedcentral.com/submit
Biomed Central 